\title{
Hepatitis $B$ virus $X$ protein impedes the DNA repair via its association with transcription factor, TFIIH
}

Ishtiaq Qadri ${ }^{*}$, Kaneez Fatima' ${ }^{1}$, Hany AbdeL-Hafiz ${ }^{2}$

\begin{abstract}
Background: Hepatitis B virus (HBV) infections play an important role in the development of hepatocellular carcinoma (HCC). HBV X protein ( $\mathrm{HBX}$ ) is a multifunctional protein that can modulate various cellular processes and plays a crucial role in the pathogenesis of HCC. HBx is known to interact with DNA helicase components of TFIIH, a basal transcriptional factor and an integral component of DNA excision repair.

Results: In this study, the functional relevance of this association was further investigated in the context to DNA repair. By site-directed mutagenesis HBx's critical residues for interaction with TFIIH were identified. Similarly, TFIIH mutants lacking ATPase domain and the conserved carboxyl-terminal domain failed to interact with HBx. Yeast and mammalian cells expressing $H B x^{\text {wt }}$ conferred hypersensitivity to UV irradiation, which is interpreted as a basic

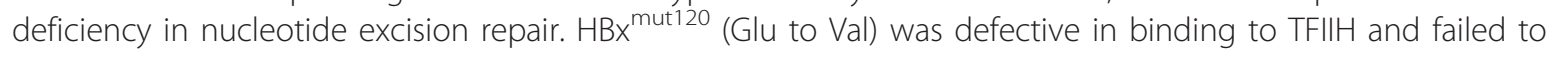
respond to UV.
\end{abstract}

Conclusions: We conclude that HBx may act as the promoting factor by inhibiting DNA repair causing DNA damage and accumulation of errors, thereby contributing to HCC development.

\section{Background}

Hepatitis B virus (HBV) infection in humans is a major health problem and is one of the principal causative agents of liver disease. It is estimated that over 500 million individuals are infected with HBV worldwide and 1 million deaths are annually attributed to the effects of HBV infection [1-3]. The virus is associated with both acute and chronic liver disease. Although the sequence of events in the development of hepatocellular carcinoma remains poorly defined, a significant correlation has been made between long-term carriage of the virus and the development of HCC [1]. Modes of HBV infection are generally from mother to infant (vertical) and by sexual routes. The direct or indirect role of HBV in the development of HCC appears complex. First, in the absence of reproducible in vitro HBV propagation system, the pathogenesis steps are poorly understood.

\footnotetext{
* Correspondence: ishtiaq80262@yahoo.com

'NUST Center of Virology and Immunology, National University of Science and Technology, Academic Block, Kashmir Highway, H-12 Islamabad, Pakistan

Full list of author information is available at the end of the article
}

Second, there is a lack of evidence for HBV replication in tumor cells that arise in HBV infected patients, despite active replication in surrounding non-tumorous hepatocytes. Furthermore, it has been observed that virtually $100 \%$ of woodchucks chronically infected with WHV at birth develop liver cancer and die of HCC [4]. Several mechanisms by which HBV infection could lead to the development of HCC have been proposed. These mechanisms include insertional mutagenesis upon integration, trans-activation of the cellular genes, activation of signaling pathways, inactivation of tumor suppressor proteins, synergy with environmental carcinogenesis and host immune response.

One of the open reading frames of the HBV genome encodes a protein termed HBx. HBx is required for viral infection and has been implicated in virus-mediated liver oncogenesis. The HBx protein has been detected in liver tissue from patients with chronic HBV infection, cirrhosis and hepatoma [5-10]. It is now generally acknowledged that HBx supplied in trans can increase gene expression of a wide variety of viral and cellular promoters and enhancer elements [11,12]. Recent
C Biomed Central

C 2011 Qadri et al; licensee BioMed Central Ltd. This is an Open Access article distributed under the terms of the Creative Commons Attribution License (http://creativecommons.org/licenses/by/2.0), which permits unrestricted use, distribution, and reproduction in any medium, provided the original work is properly cited. 
studies have demonstrated that $\mathrm{HBx}$ possesses both cytoplasmic and nuclear specific activities. A number of cytoplasmic activities have been attributed to $\mathrm{HBx}$ including, the activation of Ras/Raf/mitogen-activated protein (MAP) kinase, MEKK1/Jun kinase, [13] protein kinase C signal transduction pathways [14]. Several putative nuclear targets of $\mathrm{HBx}$ have been revealed including, ATF-2/CREB transcriptional factors [15-17], RNA polymerase subunit RPB5 $[18,19]$, tumor suppressor protein p53 $[20,21]$, TATA binding protein (TBP) [22], a putative DNA repair protein UV-DDB $[23,24]$, TFIIH [25,26], and RNA polymerase II [19]. AP-2 and $\mathrm{C} / \mathrm{EBP}$ have also been implicated as potential targets of $\mathrm{HBx}$ [27]. HBx has been shown to stimulate transcription by RNA Polymerase II and III [28]. Further, HBx was shown to induce either p53-mediated [29] or tumor necrosis factor alpha (TNF $\alpha)$-mediated apoptotic destruction of liver cells [30-32].

The functional role of $\mathrm{HBx}$ during the HBV life cycle was defined by transfecting a mutant HBV genome, lacking functional $\mathrm{HBx}$. In this case, a poor production of viral proteins was observed [33]. In woodchucks an essential functional role of $\mathrm{HBx}$ in vivo was revealed, by the use of HBx mutant. HBx (-) mutant of woodchuck failed to replicate in their natural host [34]. Although, in woodchucks $\mathrm{HBx}$ was shown to be important for establishment of virus infection [34,35], the molecular mechanism of $\mathrm{HBx}$ activity and its possible influence on cell proliferation remains obscure.

We have shown that $\mathrm{HBx}$ interacts with the XPD/ ERCC2 and XPB/ERCC3 components of TFIIH and stimulates the DNA helicase activity of TFIIH [25]. This was further substantiated by Haviv and co-workers [28]. Further, we showed that $\mathrm{HBx}$ interacts with singlestranded nucleic acids in vitro [36], the implications of which in DNA repair process remains to be investigated. TFIIH is a multiprotein complex of 10 polypeptides [37]. Apart from being an important factor of basal transcriptional machinery, TFIIH has been clearly shown to be an integral component of the DNA repair pathway [38-41].

In this study we explore the physiological relevance of HBx's association with TFIIH in the context of DNA excision repair. Although, interaction of $\mathrm{HBx}$ with a probable cellular repair protein UV-DDB was earlier reported by Lee and co-workers [42], a functional role in DNA repair which may result in lethal or hepatocarcinogenic mutations is not understood. This is also primarily due to the fact that a more defined role of UV-DDB in vitro DNA repair reaction is not established. Aboussekhra and co-workers $[43,44]$ have shown that the addition of UV-DDB during in vitro DNA repair reaction had a very modest effect on the repair synthesis. On the other hand TFIIH has been shown to be an essential component of DNA repair both in vivo and in vitro $[43,45,46]$
Support for the role of HBx in DNA repair comes from experiments with the S. cerevisiae and mammalian cells expressing $\mathrm{HBx}$, which displayed an increased UV hypersensitivity. Because of the high degree of homology between yeast and mammalian NER machinery, we have chosen yeast nuclear extracts to investigate the biochemical role of HBx in NER in vitro. Further, S. cerevisiae offers an elegant genetic background to identify the pathways by which HBx may affect this process. In this context, we used mutant yeast extracts with various genetic mutations to investigate the role of $\mathrm{HBx}$ in the NER pathways. Our results are consistent with the hypothesis that HBx impedes the DNA repair process.

\section{Methods}

\section{Saccharomyces cerevisiae strains and plasmids}

The genotype of $\mathrm{S}$. cerevisiae wild type strain 334 is MAT $\alpha$ pep4-3 prb1-1122 ura3-52 leu2-3, 112 regI-50 gal1. Two NER defective yeast strains rad 1 and rad51 were employed in this study. The genotype of Rad1 is $(\alpha$ rad1-2 his3 $\Delta 1$ leu2-3-112 lys 1-1 trp1-289 ura3-52) and $\operatorname{rad} 51$ ( $\alpha$ rad51-1 his3 $\Delta 1$ leu2-3-112 lys 1-1 trp1-289 ura3-52). Plasmids pUC18 and pBR322 were used for repair synthesis assays and were purified as described [47]. Plasmid pSBDR contains sequences encoded by an HP1 to Taq1 fragment derived from HBV adw strain which includes enhancer 1 element followed by $\mathrm{X}$ promoter, the $\mathrm{HBx}$ coding sequences and the polyA addition site. In addition, pSBDR contains neomycin resistance marker for selection in eukaryotic cells.

\section{UV survival profile of HBx expressing yeast cells}

Yeast cultures of strain 334 containing plasmids, pYES and pYES- $\mathrm{X}^{\mathrm{wt}}$ and $\mathrm{pYES}-\mathrm{X}^{\text {mutant }}$ (as indicated) were grown in $2 \mathrm{ml}$ of YMIN media $(0.17 \%$ yeast nitrogen base, $1 \%$ succinic acid, $0.6 \% \mathrm{NaOH}$ and $0.5 \%$ Ammonium sulfate) with $2 \%$ glucose. Saturated yeast cultures were washed in water and resuspended into $2 \mathrm{ml}$ of sterile water. Then $200 \mu \mathrm{l}$ of washed cells were added into $2 \mathrm{ml}$ of fresh YMIN media containing $2 \%$ glycerol, $2 \%$ ethanol and $2 \%$ galactose for the induction of $\mathrm{HBx}$ and grown with shaking $(200 \mathrm{rpm})$ for $24 \mathrm{~h}$. Various cell dilutions were plated simultaneously onto two sets of YMIN plates containing 2\% glycerol, 2\% ethanol and 2\% galactose. One set of plates was immediately irradiated under a germicidal lamp for various dosages of UV light and another set of control plates was not exposed to UV-irradiation. Plates were then incubated in dark for at least $24 \mathrm{~h}$ and shifted to $30^{\circ} \mathrm{C}$. Colonies were counted to determine the survival fraction.

UV survival profile of HBx expressing human liver cells HBx expression plasmid pSBDR and UV-damaged pRC/ CMV were co transfected into Chang liver cells. Plates 
were incubated in dark for 2 weeks in the presence of $0.4 \mathrm{mg} / \mathrm{ml}$ of G-418. The number of G-418 resistant clones per $10^{5}$ cells is plotted. Live cells were counted by staining with trypan blue after transfection and prior to $\mathrm{G}-418$ selection.

\section{Yeast nuclear extracts}

Yeast cells were grown at $30^{\circ} \mathrm{C}$ in 1 liter YPD medium (1\% yeast extracts, $2 \%$ Bactopeptone, 2\% Dextrose) to logarithmic phase. Cells were harvested by centrifugation for 10 min, washed in water, and suspended at $0.1 \mathrm{~g} / \mathrm{ml}$ in $0.1 \mathrm{M}$ EDTA pH 8.0/10 mM dithiothreitol. After incubation at $30^{\circ} \mathrm{C}$ with shaking $(50 \mathrm{rpm}$ ) for $10 \mathrm{~min}$, cells were pelleted by centrifugation as described above and suspended at 1 $\mathrm{ml}$ in YPS solution (1\% yeast extract, $2 \%$ Bactopepetone and $1 \mathrm{M}$ sorbitol) and yeast lytic enzyme (ICN) was added at $150 \mathrm{U} / \mathrm{g}$ of cells. Following incubation at $30^{\circ} \mathrm{C}$ with shaking $(50 \mathrm{rpm})$ for $2 \mathrm{hrs}$, ice cold YPS solution was added (10 mg/g of cells). Spheroblasts were pelleted by centrifugation as above and washed three times in the same buffer. Phenylmethanesulfonyl flouride was added $(0.5 \mathrm{mM})$ before the final centrifugation. Cells were washed again in $1 \mathrm{M}$ sorbitol and suspended at $0.125 \mathrm{~g} / \mathrm{ml}$ in $5 \mathrm{mM}$ Tris- $\mathrm{HCl}$, (pH7.4) $20 \mathrm{mM} \mathrm{KCl}, 2 \mathrm{mM}$ EDTA$\mathrm{KOH},(\mathrm{pH} 7.4), 0.125 \mathrm{mM}$ sperimidine, $0.05 \mathrm{M}$ sperimine, $18 \%$ Ficoll, $1 \%$ thiodiglycol and with protease inhibitors. Spheroplasts were lysed in a motor-driven homogenizer with 10 strokes. The lysates were centrifuged in a sorvall SW34 rotor at $10000 \mathrm{rpm}$ for $10 \mathrm{~min}$ and then for $5 \mathrm{~min}$ at $4^{\circ} \mathrm{C}$. The nuclei were harvested by centrifugation at $13000 \mathrm{rpm}$ for $30 \mathrm{~min}$ at $4^{\circ} \mathrm{C}$. Nuclei were resuspended $(0.6 \mathrm{ml} / \mathrm{g}$ of nuclei) in $100 \mathrm{mM}$ Tris acetate $(\mathrm{pH} 7.9), 50$ $\mathrm{mM}$ Potassium Acetate, $10 \mathrm{mM} \mathrm{MgSO}_{4}, 2 \mathrm{mM}$ EDTA, 3 $\mathrm{mM}$ DTT, $20 \%$ glycerol and protease inhibitors. Then, a solution of $4 \mathrm{M} \mathrm{NH}_{4} \mathrm{SO}_{4}$ neutralized with $\mathrm{NaOH}$ was slowly added to $0.9 \mathrm{M}$, gently stirred and centrifuged in a sorvall SW34 rotor at $12000 \mathrm{rpm}$ for $1 \mathrm{~h}$ at $4^{\circ} \mathrm{C}$. The supernatant was adjusted to $75 \%$ saturation with solid $\mathrm{NH}_{4} \mathrm{SO}_{4}$ and neutralized with $\mathrm{NaOH}$. Precipitates were collected by centrifugation in a sorvall SW34 rotor at $12000 \mathrm{rpm}$ for $15 \mathrm{~min}$ at $4^{\circ} \mathrm{C}$, resuspended in $1 / 15$ th volume of high-speed supernatant in $20 \mathrm{mM}$ Hepes- $\mathrm{KOH}$ (pH 7.6), $10 \mathrm{mM} \mathrm{MgSO} 4,5 \mathrm{mM}$ DTT, 10 mM EGTA, $20 \%$ glycerol (v/v) and protease inhibitors and dialyzed against the same buffer. Precipitates formed during dialysis were removed by centrifugation and the resulting nuclear extracts were stored at $-70^{\circ} \mathrm{C}$.

\section{In vitro DNA repair reaction}

The repair reaction contained, $0.3 \mu \mathrm{g}$ of unirradiated pUC18 and $0.3 \mu \mathrm{g}$ of UV irradiated pBR322 substrate, $45 \mathrm{mM}$ HEPES-KOH ( $\mathrm{pH} 7.8$ ), $70 \mathrm{mM} \mathrm{KCl}, 7.4 \mathrm{mM}$ $\mathrm{MgCl}_{2}, 0.9 \mathrm{mM}$ DTT, $0.4 \mathrm{mM}$ EDTA, $2 \mathrm{mM}$ ATP, 20 $\mathrm{mM}$ each of dGTP, dCTP, and dTTP, and $8 \mu \mathrm{M}$ dATP,
$2 \mu \mathrm{Ci}[\alpha-32] \mathrm{dATP}(3000 \mathrm{Ci} / \mathrm{mmol}), 40 \mathrm{mM}$ phosphocreatine, $2.5 \mathrm{mg}$ creatine phosphokinase (type 1), 3.4\% glycerol, $18 \mathrm{mg}$ bovine serum albumin and $100 \mu \mathrm{g}$ of cell extracts. Reactions were incubated for $6 \mathrm{~h}$ at $30^{\circ} \mathrm{C}$. Reactions were stopped by the addition of EDTA and then incubated with RNAse, SDS and proteinase K. Plasmids were digested with HindIII and loaded on 1\% agarose gel. After overnight electrophoresis, the gel was photographed under near-UV transillumination with Polaroid film and an autoradiograph of the dried gel was obtained.

\section{Synthesis and purification of an oligonucleotide containing a single 1.3-intrastrand d(GpTpG)-Cisplatin cross-link}

Purified 24-mer oligonucleotide containing a unique GTG sequence (5'-TCT TCT TCT GTG CAC TCT TCT TCT-3') was allowed to react at a concentration of $1 \mathrm{mM}$ with a 3 -fold molar excess of Cisplatin $(3 \mathrm{mM})$ for $16 \mathrm{~h}$ at $37^{\circ} \mathrm{C}$ in a buffer containing $3 \mathrm{mM} \mathrm{NaCl}, 0.5$ $\mathrm{mM} \mathrm{Na}_{2} \mathrm{HPO}_{4}$ and $0.5 \mathrm{mM} \mathrm{NaH}_{2} \mathrm{PO}_{4}$ [48]. The purification of the platinated oligo was done by using $20 \%$ preparative denaturing polyacrylamide gel. The oligonucleotides were visualized using a hand-held UV lamp $(254 \mathrm{~nm})$ after placing the appropriate region of the gel onto TLC plate. The desired platinated oligonucleotide was excised, crushed and suspended in $1 \mathrm{ml} \mathrm{H}_{2} \mathrm{O}$. The suspension was incubated overnight with agitation. The supernatant containing the platinated oligo was lyophilized and purified using Sephadex G25 column.

\section{Synthesis and purification of covalently closed circular DNA (cccDNA)}

Covalently closed circular DNA containing a single 1,3intrastrand d(GpTpG)-Cisplatin cross link (pt-GTG) was produced by priming $30 \mu \mathrm{g}$ of plus strand M13 mp18 DNA modified to contain a sequence complementary to the platinated oligonucleotide within the polycloning site [48] with a 5-molar excess of 5'-phosphorylated platinated oligonucleotide in a $200-\mu \mathrm{l}$ reaction mixture containing $10 \mathrm{mM}$ Tris- $\mathrm{HCl}$ (pH7.9), $50 \mathrm{mM} \mathrm{NaCl}, 10$ $\mathrm{mM} \mathrm{MgCl} 2,1 \mathrm{mM}$ DTT, $600 \mu \mathrm{M}$ each of dATP, dCTP, dGTP and TTP, 2 mM ATP, 60 units of T4 DNA polymerase and T4 ligase (New England Biolab) for $4 \mathrm{~h}$ at $37^{\circ} \mathrm{C}$. Closed circular DNA was isolated by $\mathrm{CsCl} / \mathrm{EtBr}$ density gradient centrifugation and purified by consecutive butanol extraction, centrifugation in cetricon-10 microconcentrator (Amicon) and a Sephadex G-25 column (Sigma). DNA substrates were stored at $80^{\circ} \mathrm{C}$ in 10 mM Tris- $\mathrm{HCl}, 1$ mM EDTA pH 8.0.

\section{Dual incision assay}

Ten $\mu$ r reaction mixture contain $19 \mu \mathrm{g}$ cell extract, 32 ng pt-DNA, $5 \mathrm{mM} \mathrm{MgCl}$, 40 mM HEPES-KOH pH 7.8, 
$0.5 \mathrm{mM}$ Dithiothreitol, $2 \mathrm{mM}$ ATP, $23 \mathrm{mM}$ phosphcreatine, $18 \mu \mathrm{g}$ bovine serum albumin (BRL, nuclease free). The reaction mixtures were incubated for a further 30 min. To analyze the release of DNA containing the lesion, a 34-mer oligonucleotide is used [49] as a template by sequanase to incorporate radiolabeled dCTP on the 3 ' end of the excised fragment then the excised labelled fragments were analyzed on $14 \%$ polyacrylamide gel.

\section{Results}

\section{HBx expression modulates the UV survival profile of Chang liver cells}

The effect of HBx expression on repair efficiency of a UV-damaged DNA in the human liver cell was monitored. HBx expressing plasmid pSBDR and a neomycin resistant plasmid $\mathrm{pRC/CMV} \mathrm{(control)} \mathrm{were} \mathrm{co-trans-}$ fected into Chang liver cells. In the plasmid pSBDR, the $\mathrm{HBx}$ coding sequences are placed under the transcriptional control of native promoter and enhancer. pRC/ CMV DNA was UV damaged for 2, 6, and 8 and $10 \mathrm{~J} /$ $\mathrm{m}^{2}$ of UV radiation. As a control, UV-damaged $\mathrm{pRC/}$ CMV DNA was co-transfected along with a plasmid pHEN100 lacking the coding sequences of HBx. Cells were counted prior to co-transfection and selected in media containing G-418 for 2 weeks. Thereafter, G- 418 resistant clones were counted. A decrease in the number of G-418 resistant clones per $10^{5}$ cells was observed in HBx expressing cells when compared with non-expressing cells (Figure 1).

\section{HBx mutants fail to interact with TFIIH}

We previously reported interactions between $\mathrm{HBx}$ and two components of TFIIH, ERRC2 and ERCC3 [28]. We identified a domain spanning aa 110-143, sufficient for these interactions between HBx and ERCC2 and ERCC3 [25] is domain was shown to be sufficient to stimulate the DNA helicase activity of purified TFIIH [25]. To identify the critical amino acids required for TFIIH interactions and associated functions, the conserved negatively charged residues in this domain were selected for mutagenesis studies. Using site-directed mutagenesis technique, individual amino acid residues, Asp 113, Asp 118, Glu 120, Glu 121, Glu 124 and Glu 125 were changed to non-polar Val. These $\mathrm{HBx}$ mutants were employed for interaction between HBx and ERCC2 and ERCC3. ERCC2 protein was expressed in E. Coli as a Maltose-ERCC2 fusion protein. Bacterial cellular extracts were immobilized on amylose resin. In this experiment the wild type $\mathrm{HBx}$ was in vitro translated and allowed to interact with either Mal-ERCC2 resin or with amylose beads alone. While $\mathrm{HBx}$ interacted with ERCC2 (Figure 2A, lane 1), no interaction was seen with amylose resin alone (Figure $2 \mathrm{~A}$, lane 6). In vitro translated ${ }^{35} \mathrm{~S}$ [methionine]-labeled $\mathrm{HBx}$ mutants Glu 120,
Glu 121, Glu 124, and Glu 125 proteins were allowed to interact with Mal-ERCC2 (Figure 2A, lanes 2-5). The results of this analysis show that $\mathrm{HBx}$ mutant Glu 120 and Glu 121 did not interact with Mal-ERCC2 at any significant level (lanes 2 and 3). HBx mutants Glu 124 (lane 4) and Glu 125 (lane 5) showed only a modest reduction in binding to ERCC2 (see densitometric analysis in the right panel of Figure 2A).

To map the critical residue required for the interaction of HBx with ERCC3, GST pull down assay was performed in which ERCC3 proteins were synthesized in vitro in the presence of ${ }^{35} \mathrm{~S}$ [methionine] and allowed to interact with GST-fusion protein of HBx (Figure 2B). While wild type HBx interacted with ERCC3 (lane 2), no interactions were seen with GST (lane 1). HBx's mutants Asp 113 (lane 3) and Asp 118 (lane 4) showed normal interaction with ERCC3. On the other had HBx's mutant Glu 120, Glu 121 showed a reduction in binding to ERCC3 (lane 5 and 6). No interaction has been seen with the double mutant Glu 120/121 (lane 7). Collectively, these studies are consistent in identifying the Glu 120 and Glu 121 of $\mathrm{HBx}$ as critical residues involved in interactions with both DNA helicase components of TFIIH. These HBx mutant constructs provide a stronger evidence for the specificity of our previous resorts for the protein-protein interactions.

\section{HBx mutants fail to interact with TFIIH}

The HBx mutants were tested for their ability to physically interact with the DNA helicase components of yeast TFIIH (yTFIIH). The RAD3 and SSL2 represent the homologues of ERCC2 and ERCC3 components of mammalian TFIIH. In the first experiment, ${ }^{35} \mathrm{~S}$-[methionine]-labelled wild type RAD3 component of yTFIIH was allowed to interact with glutathione affinity beads immobilized with either glutathione S-transferase (GST) or GST-HBx ${ }^{\text {wt }}$ or GST-HBx ${ }^{\text {mut }}$ fusion proteins which were extracted from bacteria (Figure 3A). After extensive washing, the bound proteins were analyzed by SDSPAGE. In this analysis only HBx mutant Glu 120 failed to interact with RAD3 (Figure 3A, lane 6). Other mutants either interacted modestly or functioned as wild type $\mathrm{HBx}$ (Figure 3A).

Next, we also employed ${ }^{35}$ S[methionine]-labelled SSL2 homology of ERCC3 for its ability to interact with GST$\mathrm{X}$ mutant proteins immobilized on GST affinity beads (Figure 3B). Consistent with Figure 3A, the results of these interaction studies identified Glu 120 as a critical residue for interaction with both components of yTFIIH.

\section{HBx expressing yeast cells modulates the UV survival profile}

To further correlate the effect of HBx associations with TFIIH, we employed a UV hypersensitivity assay as 


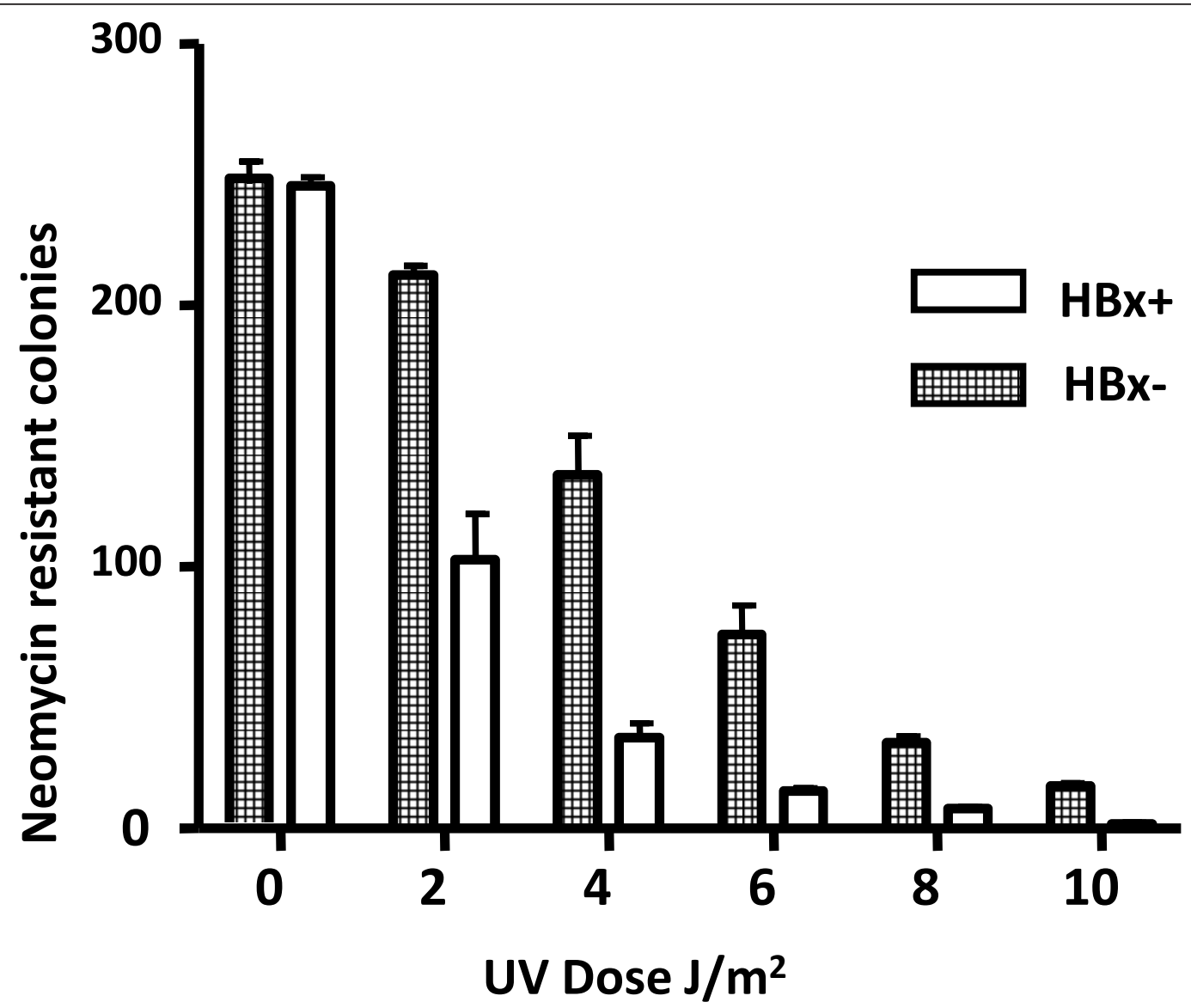

Figure 1 UV survival profile of HBx expressing human liver cells. HBx expression plasmid pSBDR and UV-damaged pRC/CMV were CO transfected into chang liver cells. Plates were incubated in dark for 2 weeks in the presence of G418. The number of G418 resistant cells per $10^{5}$ cells is plotted. Live cells were counted by staining with trypan blue prior to transfection. The ordinate represents the survival fraction, while the abscissa displays the dosage of UV irradiation. Each bar represents Mean \pm S.D. from three independent experiments.

described by Gulyas and Donahue [50]. These authors have generated a SSL2 mutant (Ssl2-xp) that mimics the ERCC3 defect found in XP patients. This non-lethal mutant allele of SSL2 was shown to increases the sensitivity of yeast to UV irradiation when tested in an in vivo assay for viability. Upon UV irradiation of yeast, in which Ssl2-xp was the sole copy, $10^{3}$ more cells died when compared to wild type, suggesting a direct correlation between defects in DNA repair enzymes and UV hypersensitivity. Using this assay system, the influence of $\mathrm{HBx}$ on DNA repair process in yeast was examined. $\mathrm{HBx}^{\mathrm{wt}}$ and selected $\mathrm{HBx}^{\text {mutants }}$ were cloned in the yeast plasmid pYES with a selectable marker (Ura3) in which $\mathrm{X}$ is under the control of inducible galactose promoter. Yeast strain that lacks the galactose repressor (GAL-80) was used to transform and subjected to UV irradiation assay as described [50]. The results of UV irradiation experiment shown in Figure 4A, clearly suggest that yeast expressing $\mathrm{HBx}$ displayed an increased UV hypersensitivity. Since, we earlier showed that HBx interacts with SSL2 and RAD3 component of TFIIH [25], it is conceivable that the interactions between HBx and SSL2 and/or RAD3 are reflected in the impediment of cellular DNA repair process. To address this issue, $\mathrm{HBx}$ point mutants were employed. HBx mutants Glu 120, 121, 124 , and 125 were transformed into yeast and assayed for UV hypersensitivity assay. $\mathrm{HBx}^{\text {mut120 }}$ which fails to interact with human and yeast TFIIH failed to influence the DNA repair in yeast (Figure 4A). The expression of $\mathrm{HBx}^{\text {mut }}$ proteins in yeast cells was confirmed by Immunoblotting. In all cases, similar levels of $\mathrm{HBx}$ expression were observed (data not shown). The results of the UV hypersensitivity assay are consistent with the hypothesis that the inability of the $\mathrm{HBx}$ to interact with TFIIH directly correlates with its inability to impede the DNA repair process.

We next asked the question, does the expression of $\mathrm{HBx}$ in the mutant yeast strain lacking the carboxyl-terminus of SSL2 (ERCC3 homologue) affect the UV survival profile? A mutant yeast strain with a deletion of 


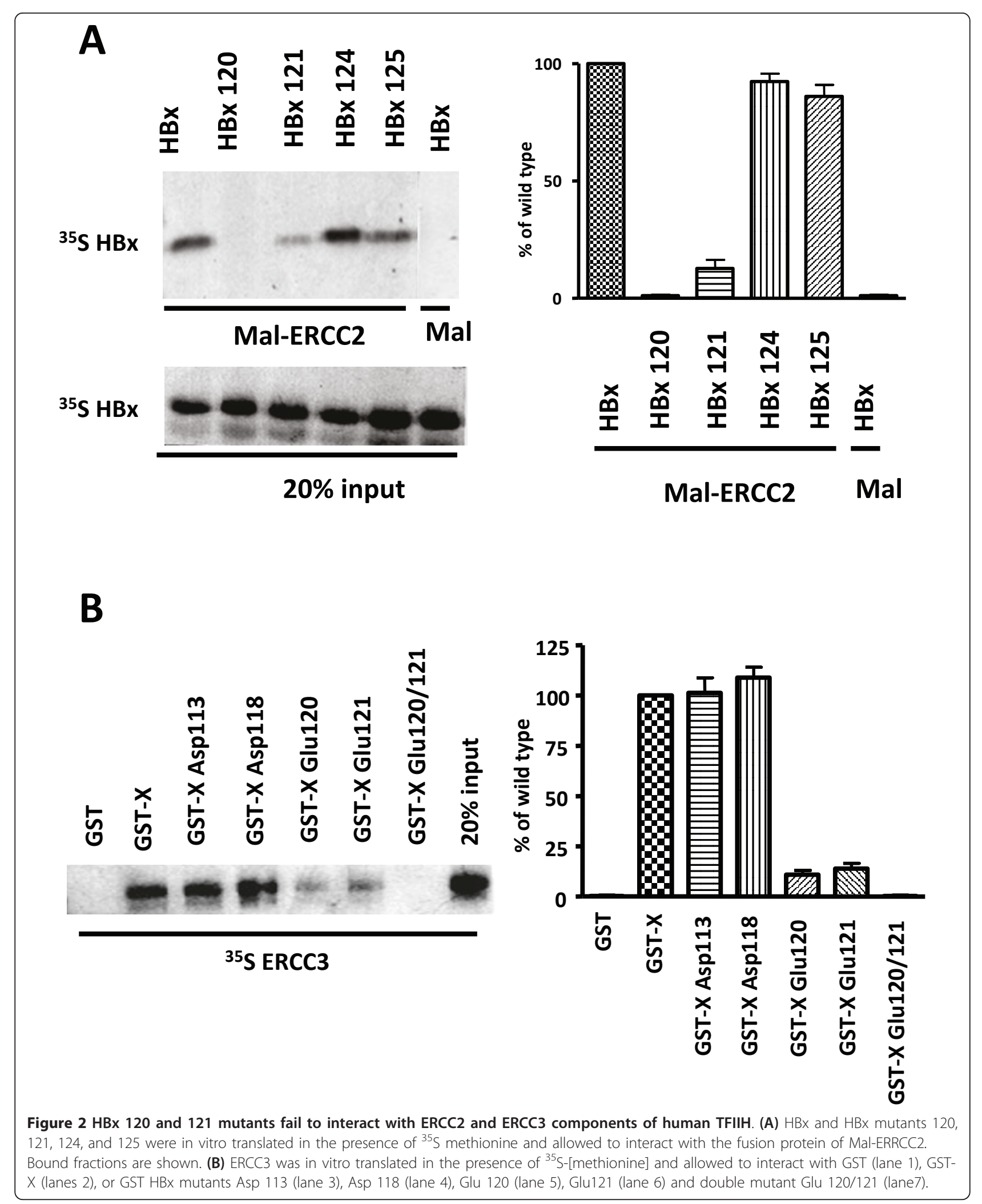




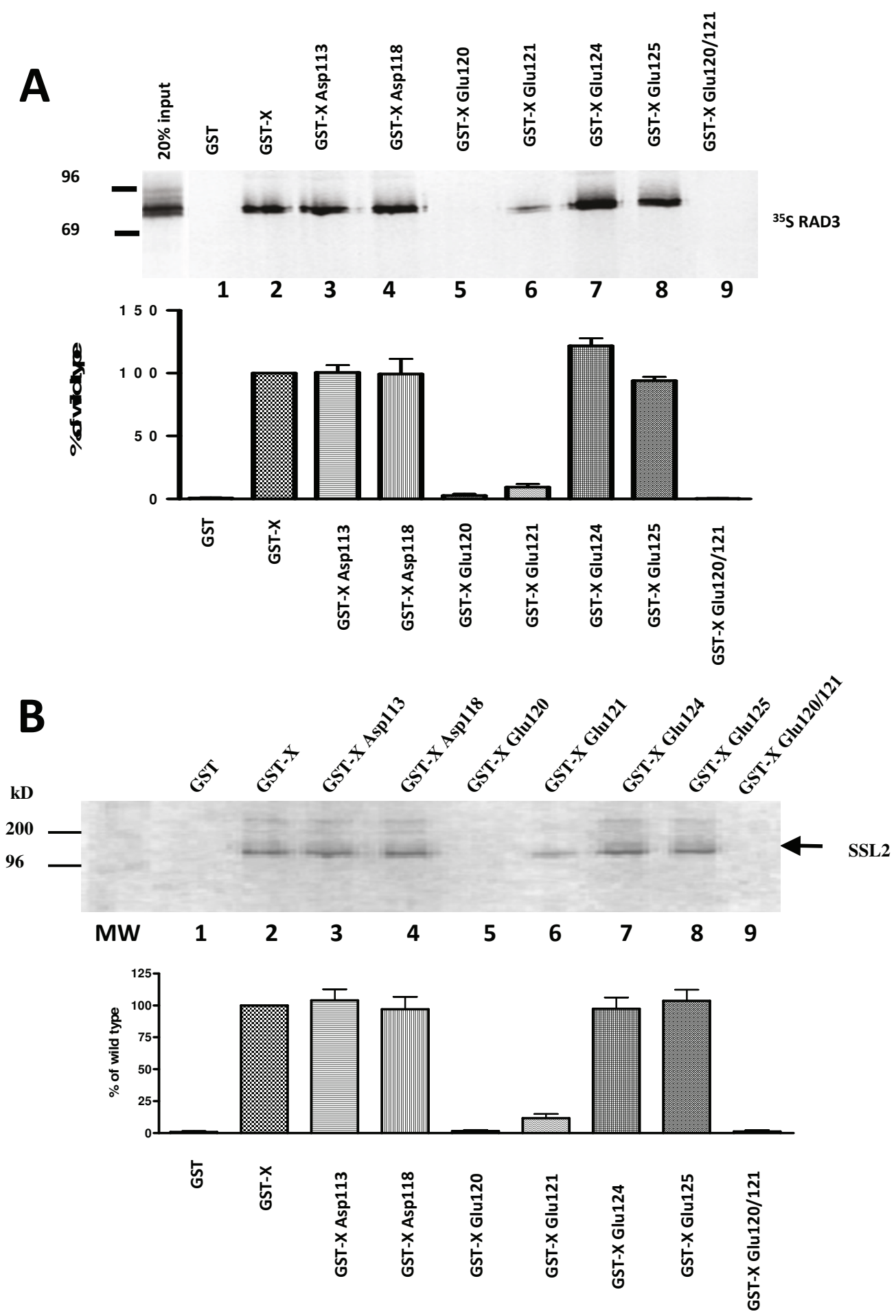

Figure 3 Reduced interaction of HBX mutants with RAD3 (ERCC2 homolog) and SSL2 (ERCC3 homolog) components of yeast TFIIH. (A) RAD3 was in vitro translated in the presence of ${ }^{35} \mathrm{~S}$ methionine and allowed to interact with GST (lane 1) or GST-X (lane 2), GST-XAsp113 (lane 3), GST-X Asp 118, (lane 4) GST-XGlu120 (lane 5), GST-X Glu121 (lane 6), GST-X Glu 124 (lane 7), GST-XGlu 125 (lane 8) and GST-X Glu 120/21 (lane 9).(B) SSL2 was synthesized in vitro and labeled with ${ }^{35} \mathrm{~S}$ methionine and allowed to interact with GST (lane 1) or GST-X (lane 2), GSTXAsp113 (lane 3), GST-X Asp 118, (lane 4) GST-XGlu120 (lane 5), GST-X Glu121 (lane 6), GST-X Glu 124 (lane 7), GST-XGlu 125 (lane 8), and GST-X Glu 120/21 (lane 9). 


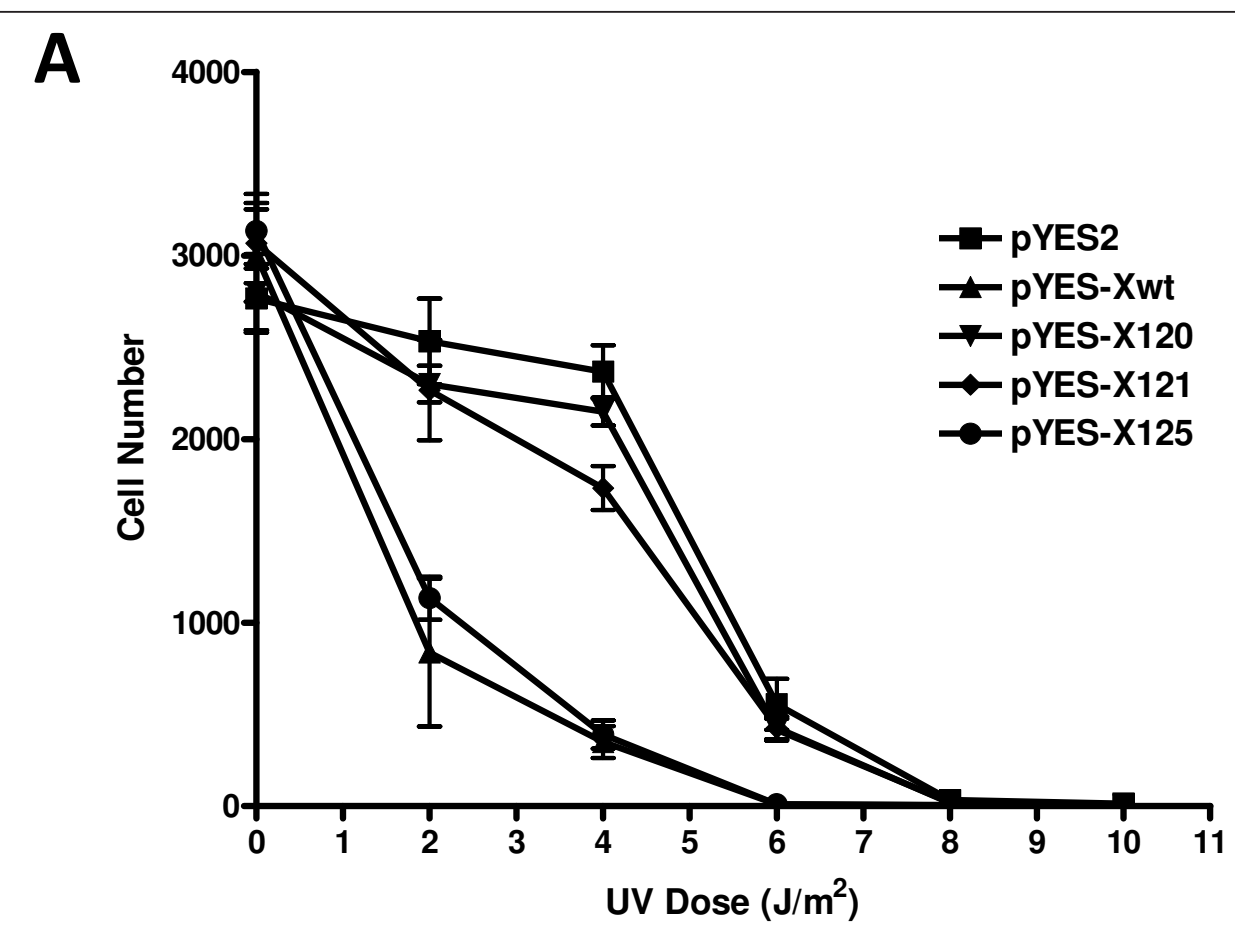

B

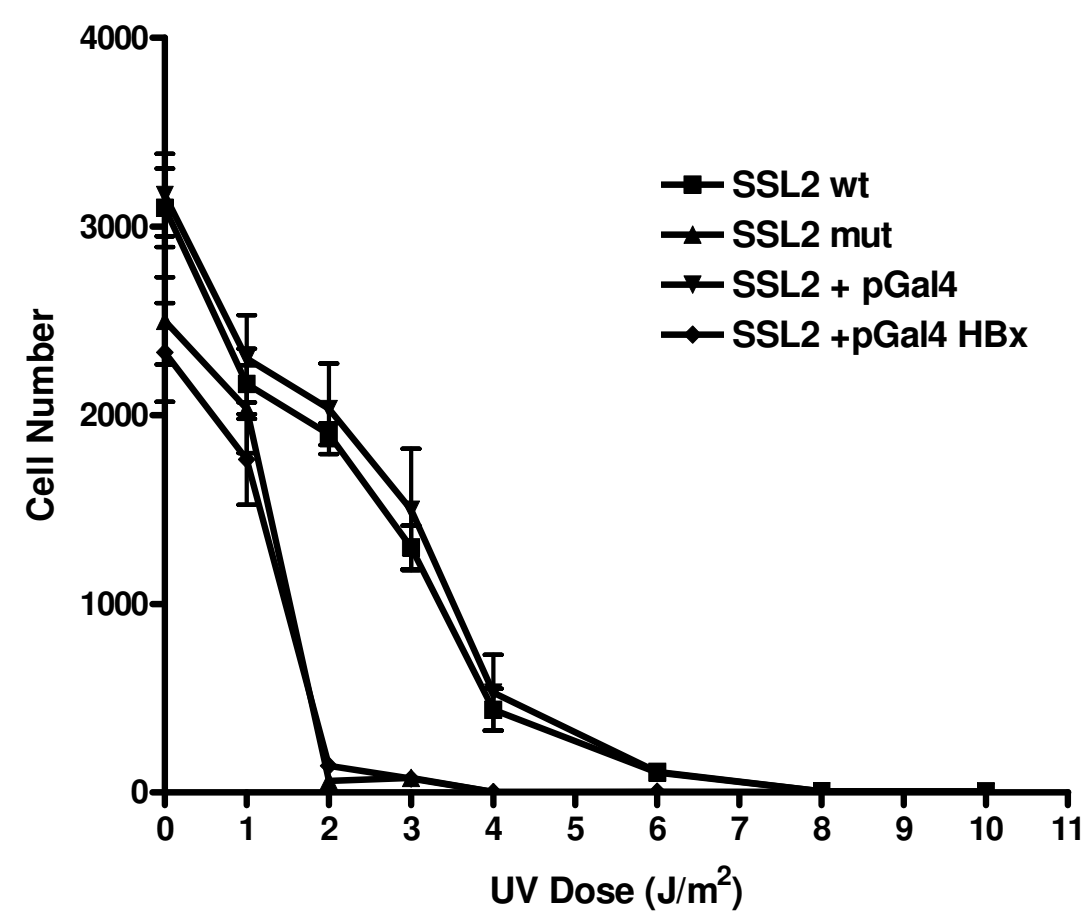

Figure $4 \mathrm{HBx}$ expression increases the UV sensitivity of yeast cells. (A) UV survival profile of HBx expressing yeast cells. Saturated yeast cultures of strain 334 containing plasmids, pYES and pYES- $X^{\text {wt }}$ and pYES-Xmuts (as indicated), were diluted in water and plated on YMIN plates containing $2 \%$ glucose, $2 \%$ glycerol, $2 \%$ ethanol and $2 \%$ galactose (for induction of HBx). Cells were immediately irradiated under a germicidal lamp. Plates were then incubated in dark for at least $24 \mathrm{hrs}$ and shifted to $30^{\circ} \mathrm{C}$. Colonies were counted to determine the survival fraction. This is the average of three experiments. The ordinate represents the survival fraction, while the abscissa displays the dosage of UV irradiation. (B) UV survival profile of HBx expression in TFIIH mutant yeast cells. This is the average of three experiments. The ordinate represents the survival fraction, while the abscissa displays the dosage of UV irradiation. 
79aa in the carboxyl terminus of was used in the UVhypersensitivity experiment [50]. The deletion in ssl2 strain overlaps with the ERCC3 deletion mutant that contains the ATPase activity and does not interact with $\mathrm{HBx}$ (data not shown). The yeast strain was transformed with plasmid pGal4- $\mathrm{X}^{\mathrm{wt}}$. In the UV hypersensitivity experiment, $\mathrm{HBx}$ did not affect the survival profile of the mutant yeast strain with $\mathrm{C}$-terminal deletion of SSL2 (Figure $4 \mathrm{~b}$ ). These results suggest that TFIIH regulated pathway is utilized by $\mathrm{HBx}$ in the impediment of the DNA repair process and that HBx-TFIIH physical interaction is crucial to influence this process.

\section{Effect of $\mathrm{HBx}$ expression on in vitro DNA repair reaction}

Next, we assayed the efficiency of HBx expressing yeast cell lysates to repair UV-damaged plasmid DNA. This was compared with non-expressing and HBx mutant expressing cell lysates. Wang and co-workers [47] developed a fairly simple and effective assay to monitor DNA repair in vitro. This assay relies on the repair synthesis of a plasmid which has been previously treated with a base-damaging agent $\mathrm{N}$-acetoxy-2-acetylaminofluorene (AAAF) or UV irradiation. Damaged plasmids are incubated with wild type yeast cell-free extracts and ${ }^{32} \mathrm{P}$-labeled dCTP. Radioactivity incorporated into the damaged plasmid during DNA repair is observed by agarose gel electrophoresis followed by autoradiography. By employing the mutant alleles of RAD3 and SSL2, Wang and co-workers [47] were able to define a functional role for yeast TFIIH in DNA repair. We employed this assay to determine the effect of $\mathrm{HBx}$ on DNA repair process in vitro. To control the specificity of in vitro DNA repair reaction, we also used TFIIH (ssl2) mutant and NER defective rad 1 and rad51 deletion yeast strains as controls.

First, UV irradiated plasmid pBR322 was subjected to DNA repair in vitro, with extracts of wild type yeast strain 334 and those transformed with pYES-2 (vector alone), pYES-X (HBx expressing vector) and its mutants Glu 120, Glu 121, Glu 124 and Glu 125. Un-irradiated plasmid pUC18 DNA was used as a control. Yeast lysates were prepared $16 \mathrm{hr}$ after treatment with $2 \%$ galactose for the expression of $\mathrm{HBx}$ and its mutant proteins. $\mathrm{HBx}$ and its mutant proteins were expressed equally in these yeast strains as confirmed by Western blotting (data not shown).

Figure 5A shows the results of this experiment. The repair synthesis of UV irradiated plasmid pUC18 using the yeast crude extracts transformed with vector alone (lane 1), $\mathrm{HBx}$ expressing vector, (lane 2) and $\mathrm{HBx}$ mutants Glu 120 (lane 3), Glu 121 (lane 4), Glu 124 (lane 5) and Glu 125 (lane 6). The incorporation of ${ }^{32} \mathrm{P}$ [dCTP] as a measure of DNA repair is shown in Figure 5. These results clearly suggest that $\mathrm{HBx}$ expressing yeast lysates are defective in repairing the UV-damaged DNA in vitro (compare lane 1 with lane 2). HBx mutant Asp 113 that has retained the ability to interact with TFIIH (Figure $2 \mathrm{~A}-\mathrm{C}$ ) also retains the ability to impede the DNA repair process like wild type $\mathrm{HBx}$ (lane 3). Yeast lysates expressing other mutants of $\mathrm{HBx}$ showed varying degrees of DNA repair efficiencies (lanes 4-7). More importantly, HBx's mutant Glu 120 which failed to interact with TFIIH also failed to influence the repair process in vitro (lane 3). The results shown in Figure 5A are encouraging, as no incorporation in the un-damaged pBR322 DNA was observed. To further confirm that non-specific incorporation of radioactivity has not occurred in this reaction, we used HBx expressing NER defective yeast lysates. Two mutant yeast strains with deletions in Rad-1 and Rad-51 were transformed with $\mathrm{HBx}$ expressing plasmid pGAL4-X and a control plasmid pGAL4. Yeast lysates were prepared after $16 \mathrm{hrs}$ induction with $2 \%$ glacotose and subjected in repair reaction (Figure 5B, lanes 3-6). Both Rad-1 and Rad-51 NER defective lysates showed no incorporation (lanes 3 and 5). HBx expression in these mutant yeast lysates had no effect on the repair reaction (lane 4 and 6). This suggests that indeed specific DNA repair reaction has occurred in Figure 5A. These results are consistent with the hypothesis that HBx expressing wild type yeast lysates have diminished DNA repair efficiency of UV-damaged plasmid DNA.

Next, we examined the ability of HBx to alter DNA excision repair reaction in a TFIIH mutant yeast strain (Figure 5C). Wild type yeast strain and two TFIIH mutant yeast strains ssl2 (dead) and ssl2 (ts) [37] were transformed with a control plasmid pGAL4 and HBx expressing pGAL4-X DNAs. Yeast lysates were prepared as described. UV-damaged pBR322 DNA was used. Consistent with our previous results, $\mathrm{HBx}$ expression in wild type strain diminished the ability to repair the DNA (lane 2). TFIIH mutant yeast lysates with $\mathrm{HBx}$ (lane 4 and 6) or without $\mathrm{HBx}$ (lanes 3 and 5) were equally deficient in DNA repair synthesis, suggesting that $\mathrm{HBx}$ impinge its influence on DNA repair via TFIIH. In summary, using myriad experimental strategies, our results implicate $\mathrm{HBx}$ in DNA repair process via its physical interactions with the helicase components of TFIIH.

\section{HBx protein inhibits excision of damaged DNA in the dual incision assay}

To measure the effect of $\mathrm{X}$ protein on the excision of the Damaged DNA, we used $40 \mu \mathrm{g}$ of HeLa whole cell extract and $20 \mathrm{ng}$ of Pt-DNA. Figure 6 shows that $\mathrm{HBx}$ or $\mathrm{HBx} 113$ mutant but not $\mathrm{HBx} 120$ or $\mathrm{HBx} 121$ is able to inhibit the excision of the platinated fragment.

\section{Discussion}

HBx protein has been proposed to play a role in the development of HCC. HBx has been shown to possess 


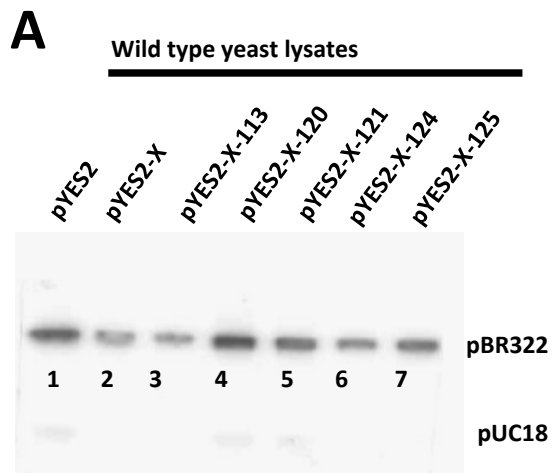

$\begin{array}{lllllll}100 & 21.6 & 18.4 & 116 & 98.3 & 25.3 & 34.1\end{array} \%$ of control

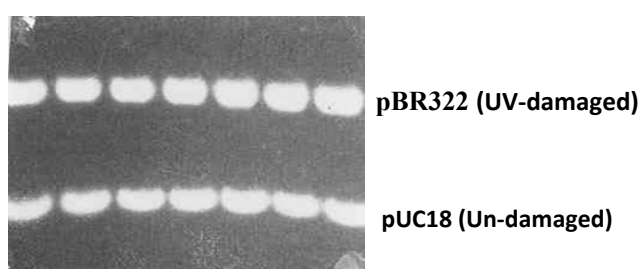

$\begin{array}{lllllll}1 & 2 & 3 & 4 & 5 & 6 & 7\end{array}$

B
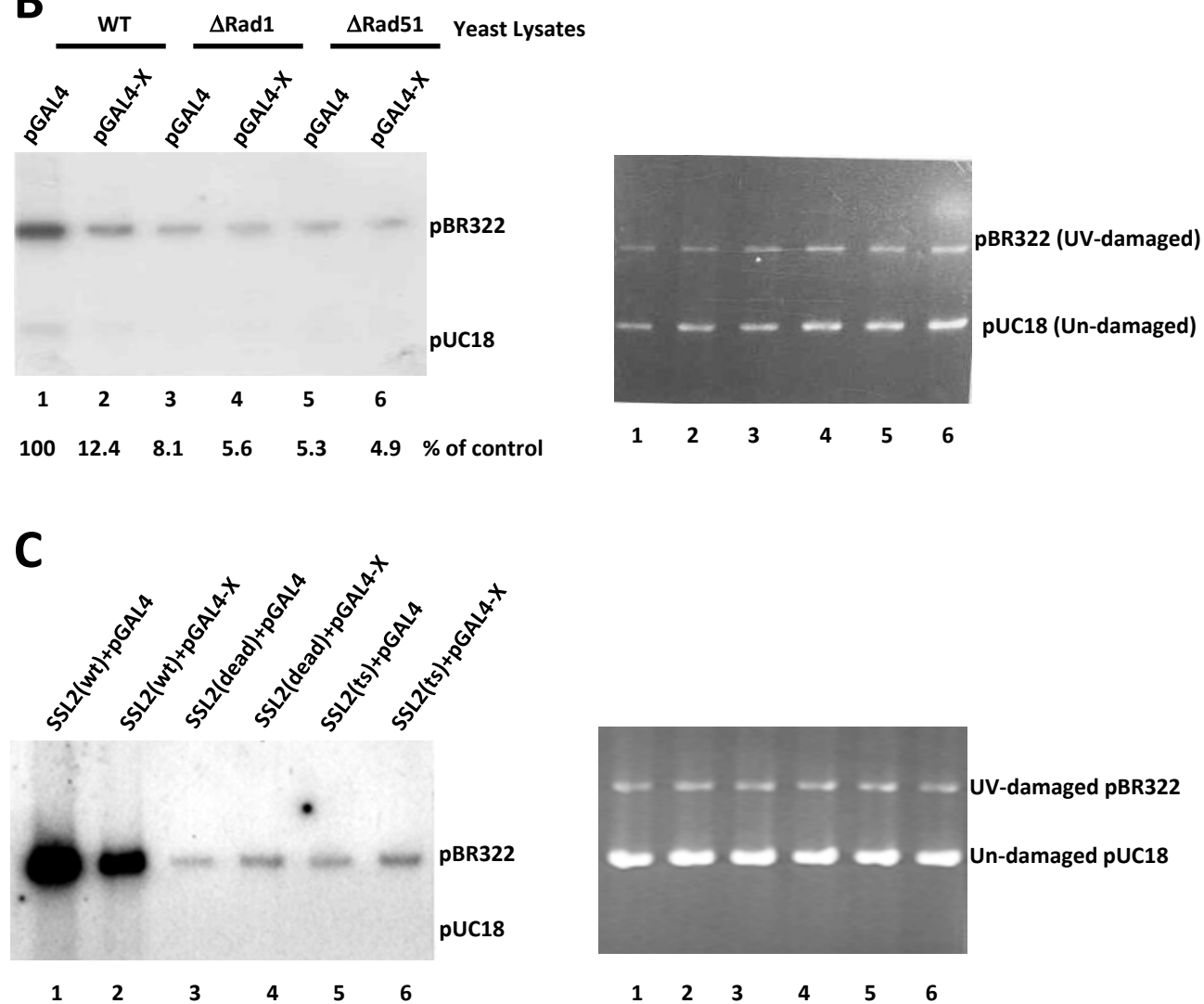

Figure 5 HBx impedes the DNA repair of UV damaged plasmid DNA in-vitro. (A) In vitro repair of UV-damaged pBR322 DNA using yeast lysates expressing $\mathrm{HBx}$ and its mutants. The repair reaction contained, $0.3 \mu \mathrm{g}$ un-irradiated pUC18 and $0.3 \mu \mathrm{g}$ UV-irradiated pBR322 substrate, was performed as discussed in the experimental procedure. Control plasmid (lane 1); HBx expressing plasmid (lane 2); and its mutant Glu120 (lane 3); Glu 121 (lane 4); Glu 124 (lane 5) and Glu 125 (lane6). Reactions were incubated for 6 hours at $30^{\circ} \mathrm{C}$. Reactions were stopped by the addition of EDTA and then incubated with RNAse, SDS and proteinase K. Plasmids were digested with Hindlll and loaded on $1 \%$ agarose gel. After overnight electrophoresis, the gel was photographed under near-UV transillumination with Polaroid film (right panel) and an autoradiograph of the dried gel was obtained (left panel) (B) HBx is unable to repair the damaged plasmid DNA in Rad1 and Rad51 mutant yeast strain. Plasmid p-GAL4 and pGAL4-X were transformed into yeast strains with normal RAD1 and RAD51 genes (lane 1, 2), with deletion of Rad1 (lane 3,4) and with deletion of RAd51 (lane 5-6). Nuclear extract were assayed for DNA repair of UV-damaged pUC18 DNA (C) HBx is unable to repair damaged plasmid DNA in SSL2 mutant (dead) and temperature sensitive yeast strain. Plasmid p-Gal4 and pGAL4-X were transformed into yeast strains with normal SSL2 (lane 1,2) mutant SSL2-dead strain (lane 3,4) and temperature strain (lane 5-6). Nuclear extracts were assayed for DNA repair of UV-damaged pBR322 DNA The yeast ts strain was grown at room temperature $\left(20-21^{\circ} \mathrm{C}\right)$. 


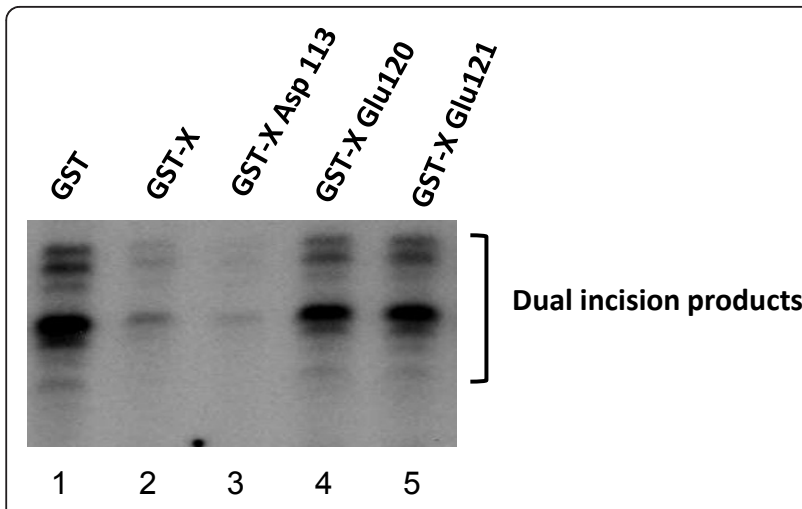

Figure 6 HBx protein inhibits excision of damaged DNA in dual incision assay. Measurement of the effect of $X$ protein on the dual excision of the Damaged DNA using $40 \mu \mathrm{g}$ of HeLa whole cell extract and 20 ng of Pt-DNA. GST (lane 1) or GST-X (lane 2), GSTXAsp113 (lane 3), GST-XGlu120 (lane 4), GST-X Glu121 (lane 5).

pleiotropic functions including impairment of cell cycle progression [51], interaction with transcription machinery [9-13], and cell signal transduction and apoptosis mechanisms [29,52-54]. Furthermore, HBx associated physically with p53 resulting in the sequestration of p53 in the cytoplasm (28), inhibition of p53 function including its DNA binding and transactivation activities [55] as well as p53 interaction with XPB protein [55]. Several studies suggested a potential role of HBx cellular DNA repair process. This is borne out by its associations with TFIIH $[25,28]$, a probable DNA repair factor UV-DDB $[23,42,56]$, p53 tumor suppressor protein $[55,57]$, ssDNA [36], and UV-damaged DNA [58,59].

\section{HBx expression inhibit DNA repair}

Our study provides evidence that HBx can inhibit DNA repair pathway. In the absence of UV damage, cells expressing HBx were found to be similar to control cells in cell growth measured by colony formation assay (Figure 1). Similar observations were reported by Lee and co-workers [60]. They demonstrated that $\mathrm{HBx}$ expression did not affect the morphology, viability, and cell cycle/apoptosis profiles or DNA repair machinery of UV-untreated HepG2 cells. However, HBx-expressing cells exhibited increased sensitivity to UV damage and reduced DNA repair capacity. It has been shown that mice carrying $\mathrm{HBx}$ as a transgene show a direct correlation between the level of HBx expression and the likelihood to develop HCC $[61,62]$. However certain lineages of $\mathrm{HBx}$ transgenic mice do not exhibit tumour development unless coupled with other factors such as exposure to the hepatocarcinogen diethylnitrosamine [63] or when combined with $c$-myc induction [64]. It has been suggested previously that $\mathrm{HBx}$ does not directly cause cancer but plays a role in liver oncogenesis as a cofactor or tumour promoter [60]. Chronic HBV infection may present a long-term opportunity for an initiating event to occur, and HBx may act by modifying cellular regulatory/control mechanisms facilitating the culmination of the transformation process in the cell. In this regard, a highly probable tumour-initiating event is DNA damage.

\section{HBx mutants failed to interact with TFIIH}

We continue to characterize the specific domains of $\mathrm{HBx}$ involved in affecting the DNA repair process. We have employed approaches to elucidate the mechanism (s) by which HBx interactions with DNA excision repairs factor TFIIH could lead to impaired DNA repair. DNA repair system is the primary defence against accumulation of mutations in genomic DNA and activation of cellular carcinogenesis. Deficiencies in DNA repair pathways have been linked to common cancer predisposition syndromes. Notable among these are the hereditary nonpolyposis colorectal cancer (HNPCC) and skin cancer or xeroderma pigmentosum $[46,65]$. DNA repair occurs by kinetically two different pathways: one involved with repair of the overall genome (global repair) and one involved with repair of transcribed genes (transcription coupled-repair) $[46,66,67]$. Studies have demonstrated that some of the essential DNA repair proteins in yeast and mammalian cells are a part of basal transcription factor TFIIH $[26,67,68]$. In humans, the defects in XPD/ERCC2 and XPB/ERCC3 genes lead to xeroderma pigmentosum (XP) [69] and Cockayne's Syndrome (CS) $[65,66]$. Both conditions are manifested by the inability of the cells to efficiently repair damaged DNA. In yeast, RAD3 and SSL2 (RAD25) are the homologues of XPD/ERCC2 and XPB/ ERCC3 respectively. These genes are essential both in yeast and mammals.

Since TFIIH is one of the minimal set of factors required for transcription initiation and DNA excision repair, the association of $\mathrm{HBx}$ implicates a fundamental role in the processes affected by HBx [70,71]. A large body of data, supports the transcriptional transactivation role of $\mathrm{HBx}[11,72,73]$. It remains to be determined if HBx's ability to stimulate DNA helicase activity of ERCC2/ERCC3 [25] is functionally relevant to both DNA repair and transcription initiation.

\section{Mapping of the functional domain of $\mathrm{HBx}$}

Many studies showed that $\mathrm{HBx}$ plays an important role in HCC pathogenesis by interacting with cellular oncogenes [21-23] and that its functional domain involved in oncogenesis is at the middle of HBx protein $[24,25]$. Several studies have also shown that HBx can induce apoptosis [26-29].

Tang and co-worker has mapped the coactivation domain within the C-terminal, two thirds of which 
(aa51-138) is identified to that of the transactivation. In contrast, the $\mathrm{N}$-terminal of $\mathrm{HBx}$ has the ability to down regulate transactivation and was defined as the negative regulatory domain [74].

It has been shown recently that the $\mathrm{COOH}$-terminal truncated HBx plays a critical role in the HCC carcinogenesis via the activation of cell proliferation [75]. Alteration of HBV X gene has been detected more frequently in tissue samples of cirrhosis and/or HCC than in those of mild liver disease [76]. However, the mechanism of $\mathrm{HBx}$ in $\mathrm{HCC}$ carcinogenesis is still unclear, although many studies have associated it to ability of HBx trans-activating cellular oncogenes and signaling cascades that stimulate cell proliferation and lead to HCC carcinogenesis [1,17,77-79]. It has been demonstrated that the full-length $\mathrm{HBx}$ contains two function domains: oncogenic domain (the NH2 terminal through middle peptide) and proapoptotic domain (the $\mathrm{COOH}$-terminal peptide). There is a balance between these two functions in HBV-infected hepatocytes. When the proapoptotic domain is deleted by an unknown mechanism during the viral integration, the balance is broken and the oncogenic function becomes dominant, leading to the subsequent development of HCC.

HBx has been shown to enhance cell susceptibility to cytotoxic effect of genotoxic agents, e.g. UVC and aflatoxins, that induce bulky adducts. This effect has been linked to impaired regulation of DNA repair and associated cell cycle checkpoint mechanisms [24-27], and/or the proapoptotic effect of $\mathrm{HBx}$ [45]. DNA damage induced by bulky adducts are preferred substrates for NER mechanism, where the TFIIH repair complex plays an essential role [30]. Inhibition of TFIIH activity by HBx may inhibit DNA repair and hence promote cells to undergo apoptosis. While several studies have focused on the transactivation capacity of the HBx protein in carcinogenesis, our data indicates that HBX is capable of transcriptional repression while maintaining it transactivation functions on NF-kB and AP1 responsive elements. The implication of transactivation in carcinogenesis is demonstrated primarily in transient systems and there is evidence that $\mathrm{HBx}$-induced transactivation is not sufficient for cell transformation [47]. The observation that HBx suppresses XPB and XPD in liver tissue from $\mathrm{HBx}$-transgenic mice supports the biological relevance of our findings. XPB and XPD helicase and ATPase activities, but not the TFIIH kinase, are required for NER function [30-33].

Previous studies have shown that HBx inactivate the p53 tumour suppressor protein and impair DNA repair, cell cycle, and apoptosis mechanisms. HBx was shown to represses two components of the transcription-repair factor TFIIH, XPB (p89), and XPD (p80), both in p53-proficient and p53-deficient liver cells. This inhibition is observed while HBx maintains its transactivation function. Expression of HBx in liver cells results in down-regulation of endogenous XPB and XPD mRNAs and proteins. In liver tissue from $\mathrm{HBx}$ transgenic, $\mathrm{XPB}$ and $\mathrm{XPD}$ proteins are down-regulated in comparison to matched normal liver tissue [48]. HBx expression on hepatocytes nucleotide excision repair has been successfully studied in primary wild-type and $p 53$-null mouse hepatocytes. Transient $\mathrm{HBx}$ expression reduces global DNA repair in wild-type cells to the level of $p 53$-null hepatocytes and has no effect on the repair of a transfected damaged plasmid [53]. Inhibition of p53-mediated apoptosis by HBx may provide a clonal selective advantage for hepatocytes expressing this integrated viral gene during the early stages of human liver carcinogenesis [54].

To date, a few mechanisms of HBV-induced HCC have been proposed. Early studies proposed that insertional mutagenesis of the HBV genome into human chromosomes might cause inactivation of tumor suppressor/ proto-oncogenes [80-82]. However, later studies have shown that integration of HBV genome is genome-wide and unlikely attacks a specific tumor suppressor or protooncogene $[82,83]$. HBx initiates transactivation as well as induction of signal transduction pathways such as Ras/ Raf-1 $[84,85]$. The large surface protein has been shown to induce HCC in the transgenic mouse model $[86,87]$. Our results are consistent to the hypothesis that HBx impedes the DNA repair via interaction with TFIIH. In the dual incision assay HBx120 or HBx121 mutants fail to impede the repair process. These two residues seem to be critical determinant in DNA repair in HBx mediated inhibition as two mutants fail to interact with TFIIH.

\section{Conclusions}

In our study, we defined an inhibitory role of $\mathrm{HBx}$ in DNA excision repair process, thus hampering the cellular ability to repair the damaged DNA more effectively during HBx expression. Recent studies on HCC in Taiwan, the pre- $S_{1} / S_{2}$ mutant were shown to induce oxidative stress and DNA damage in Ground glass hepatocytes (GGHs), the pathological hallmarks for late phases of chronic HBV infection [88]. Other studies have reported that a defect in the ogg1 DNA repair gene is involved in various types of human carcinogenesis [89]. Therefore, efficient DNA repair for damaged DNA should play an important role in cancer prevention. Our findings suggest that $\mathrm{HBx}$ may act as the promoting factor by inhibiting DNA repair causing DNA damage and accumulation of errors, thereby contributing to HCC development.

\section{List of abbreviations}

The abbreviations used are, (HBV): hepatitis B virus; (TFIIH): transcription factor IIH; (ERCC): excision repair cross complementing; (NER): nucleotide excision repair; (XP): xeroderma pigmentosum. 


\section{Acknowledgements}

We thank Drs A Prakash and L. Prakash (University of Texas, Galveston, TX) for Yeast Rad1 and Rad51 strains and Dr. K. Guylas (Stanford University, Stanford (A) for yeast SSL2 strains. We are indebted to Drs. J. Egly and J. Hoeijmakers (INSERM, Strasbourg, France) for ERCC2 and GST-ERCC3 and Drs. JW Conaway and RC Conaway (University of Oklahoma, OK, USA) for the TFIIH purified fractions and Dr. Aleem Sidiqqui (University of California, San Diego, CA, USA) for HBx constructs. The support for this work was provided by the University of Colorado, Thorkilson Award and US State Department Grant (IQ) and the University of Colorado School of medicine grant to HAH.

\section{Author details}

'NUST Center of Virology and Immunology, National University of Science and Technology, Academic Block, Kashmir Highway, H-12 Islamabad, Pakistan. ${ }^{2}$ Department of Medicine, University of Colorado Health Sciences Center at Fitzsimons, Aurora, CO, USA.

\section{Authors' contributions}

IQ conceived the idea coupled with the design and execution of experiments and have also written the manuscript. KF and HAH performed Dual incision assay, in-vitro experiments, prepared Figures and edited the manuscript. The financial support was provided by grants to IQ and HAH.

\section{Competing interests}

The authors declare that they have no competing interests.

Received: 20 July 2010 Accepted: 4 March 2011

Published: 4 March 2011

\section{References}

1. Neuveut C, Wei Y, Buendia MA: Mechanisms of HBV-related hepatocarcinogenesis. J Hepatol 2010, 52(4):594-604

2. Fung J, Lai CL, Yuen MF: Hepatitis B and C virus-related carcinogenesis. Clin Microbiol Infect 2009, 15(11):964-970.

3. Benhenda S, Cougot D, Buendia MA, Neuveut C: Hepatitis B virus X protein molecular functions and its role in virus life cycle and pathogenesis. Adv Cancer Res 2009, 103:75-109.

4. Bruni R, Conti I, Villano U, Giuseppetti R, Palmieri G, Rapicetta M: Lack of WHV integration nearby N-myc2 and in the downstream b3n and win loci in a considerable fraction of liver tumors with activated N-myc2 from naturally infected wild woodchucks. Virology 2006, 345(1):258-269.

5. Park EH, Koh SS, Srisuttee R, Cho IR, Min HJ, Jhun BH, Lee YS, Jang KL, Kim CH, Johnston RN, et al: Expression of HBX, an oncoprotein of hepatitis B virus, blocks reoviral oncolysis of hepatocellular carcinoma cells. Cancer Gene Ther 2009, 16(5):453-461.

6. Mukherji A, Janbandhu VC, Kumar V: HBx protein modulates PI3K/Akt pathway to overcome genotoxic stress-induced destabilization of cyclin D1 and arrest of cell cycle. Indian J Biochem Biophys 2009, 46(1):37-44.

7. He Y, Sun HQ, He XE, Wang WL, Lei JH: Knockdown of HBx by RNAi inhibits proliferation and enhances chemotherapy-induced apoptosis in hepatocellular carcinoma cells. Med Oncol 2009.

8. Cheng P, Li Y, Yang L, Wen Y, Shi W, Mao Y, Chen P, Lv H, Tang Q, Wei Y: Hepatitis $B$ virus $X$ protein $(\mathrm{HBx}$ ) induces $\mathrm{G} 2 / \mathrm{M}$ arrest and apoptosis through sustained activation of cyclin B1-CDK1 kinase. Oncol Rep 2009, 22(5):1101-1107.

9. Cheng B, Guo X, Zheng Y, Wang Y, Liu C, Li P: The effects of HBx gene on the expression of DNA repair enzymes hOGG1 and hMYHalpha mRNA in HepG2 cells. J Huazhong Univ Sci Technolog Med Sci 2009, 29(2):187-192.

10. Kuo CY, Wang JC, Wu CC, Hsu SL, Hwang GY: Effects of hepatitis B virus $X$ protein $(\mathrm{HBx})$ on cell-growth inhibition in a CCL13-HBx stable cell line. Intervirology 2008, 51(1):26-32.

11. Butel JS, Lee TH, Slagle BL: Is the DNA repair system involved in hepatitisB-virus-mediated hepatocellular carcinogenesis? Trends Microbiol 1996, 4(3):119-124

12. Nassal M, Schaller H: Hepatitis B virus replication. Trends Microbiol 1993, 1(6):221-228

13. Han M, Yan W, Guo W, Xi D, Zhou Y, Li W, Gao S, Liu M, Levy G, Luo X, et al: Hepatitis B virus-induced hFGL2 transcription is dependent on cEts-2 and MAPK signal pathway. J Biol Chem 2008, 283(47):32715-32729.
14. Kang-Park S, Lee JH, Shin JH, Lee Yl: Activation of the IGF-II gene by HBV$X$ protein requires PKC and p44/p42 map kinase signalings. Biochem Biophys Res Commun 2001, 283(2):303-307.

15. Choi $\mathrm{CY}$, Choi BH, Park GT, Rho HM: Activating transcription factor 2 (ATF2) down-regulates hepatitis B virus $\mathrm{X}$ promoter activity by the competition for the activating protein 1 binding site and the formation of the ATF2-Jun heterodimer. J Biol Chem 1997, 272(27):16934-16939.

16. Li B, Gao B, Ye L, Han X, Wang W, Kong L, Fang X, Zeng Y, Zheng H, Li S, et al: Hepatitis $B$ virus $X$ protein $(\mathrm{HBX})$ activates ATF6 and IRE1-XBP1 pathways of unfolded protein response. Virus Res 2007, 124(1-2):44-49.

17. Maguire HF, Hoeffler JP, Siddiqui A: HBV X protein alters the DNA binding specificity of CREB and ATF-2 by protein-protein interactions. Science 1991, 252(5007):842-844

18. Cheong JH, Yi M, Lin Y, Murakami S: Human RPB5, a subunit shared by eukaryotic nuclear RNA polymerases, binds human hepatitis $B$ virus $X$ protein and may play a role in X transactivation. EMBO J 1995, 14(1):143-150.

19. Le TT, Zhang S, Hayashi N, Yasukawa M, Delgermaa L, Murakami S: Mutational analysis of human RNA polymerase II subunit 5 (RPB5): the residues critical for interactions with TFIIF subunit RAP30 and hepatitis $B$ virus $X$ protein. J Biochem 2005, 138(3):215-224.

20. Wang JH, Yun C, Kim S, Chae S, Lee Yl, Kim WH, Lee JH, Kim W, Cho H: Reactivation of p53 in cells expressing hepatitis B virus X-protein involves p53 phosphorylation and a reduction of Hdm2. Cancer Sci 2008, 99(5):888-893.

21. Park SG, Min JY, Chung C, Hsieh A, Jung G: Tumor suppressor protein p53 induces degradation of the oncogenic protein HBx. Cancer Lett 2009, 282(2):229-237.

22. Qadri I, Maguire HF, Siddiqui A: Hepatitis B virus transactivator protein $X$ interacts with the TATA-binding protein. Proc Natl Acad Sci USA 1995, 92(4):1003-1007.

23. Bontron S, Lin-Marq N, Strubin M: Hepatitis B virus $X$ protein associated with UV-DDB1 induces cell death in the nucleus and is functionally antagonized by UV-DDB2. J Biol Chem 2002, 277(41):38847-38854.

24. Leupin O, Bontron S, Strubin M: Hepatitis B virus X protein and simian virus $5 \mathrm{~V}$ protein exhibit similar UV-DDB1 binding properties to mediate distinct activities. J Virol 2003, 77(11):6274-6283.

25. Qadri I, Conaway JW, Conaway RC, Schaack J, Siddiqui A: Hepatitis B virus transactivator protein, $\mathrm{HBx}$, associates with the components of TFIIH and stimulates the DNA helicase activity of TFIIH. Proc Natl Acad Sci USA 1996, 93(20):10578-10583.

26. Jaitovich-Groisman I, Benlimame N, Slagle BL, Perez MH, Alpert L, Song DJ, Fotouhi-Ardakani N, Galipeau J, Alaoui-Jamali MA: Transcriptional regulation of the TFIIH transcription repair components XPB and XPD by the hepatitis $B$ virus $x$ protein in liver cells and transgenic liver tissue. J Biol Chem 2001, 276(17):14124-14132.

27. Seto E, Mitchell PJ, Yen TS: Transactivation by the hepatitis B virus $X$ protein depends on AP-2 and other transcription factors. Nature 1990, 344(6261):72-74.

28. Haviv I, Vaizel D, Shaul Y: $p X$, the HBV-encoded coactivator, interacts with components of the transcription machinery and stimulates transcription in a TAF-independent manner. Embo J 1996, 15(13):3413-3420.

29. Chirillo P, Pagano S, Natoli G, Puri PL, Burgio VL, Balsano C, Levrero M: The hepatitis $B$ virus $X$ gene induces $p 53$-mediated programmed cell death. Proc Natl Acad Sci USA 1997, 94(15):8162-8167.

30. Kim WH, Hong F, Jaruga B, Zhang ZS, Fan SJ, Liang TJ, Gao B: Hepatitis B virus $X$ protein sensitizes primary mouse hepatocytes to ethanol- and TNF-alpha-induced apoptosis by a caspase-3-dependent mechanism. Cell Mol Immunol 2005, 2(1):40-48.

31. Yang $Y$, Zheng $L$, $L V G$, Jin $X$, Sheng J: Hepatocytes treated with HBV $X$ protein as cytotoxic effectors kill primary hepatocytes by TNF-alpharelated apoptosis-induced ligand-mediated mechanism. Intervirology 2007, 50(5):323-327.

32. $Y i$ YS, Park SG, Byeon $S M$, Kwon $Y G$, Jung G: Hepatitis B virus $X$ protein induces TNF-alpha expression via down-regulation of selenoprotein $\mathrm{P}$ in human hepatoma cell line, HepG2. Biochim Biophys Acta 2003, 1638(3):249-256.

33. Nakatake $H$, Chisaka O, Yamamoto $S$, Matsubara $K$, Koshy R: Effect of $X$ protein on transactivation of hepatitis $B$ virus promoters and on viral replication. Virology 1993, 195(2):305-314. 
34. Chen HS, Kaneko S, Girones R, Anderson RW, Hornbuckle WE, Tennant BC, Cote PJ, Gerin JL, Purcell RH, Miller RH: The woodchuck hepatitis virus X gene is important for establishment of virus infection in woodchucks. J Virol 1993, 67(3):1218-1226.

35. Zoulim F, Saputelli J, Seeger C: Woodchuck hepatitis virus $X$ protein is required for viral infection in vivo. J Virol 1994, 68(3):2026-2030.

36. Qadri I, Ferrari ME, Siddiqui A: The hepatitis B virus transactivator protein, $\mathrm{HBx}$, interacts with single-stranded DNA (ssDNA). Biochemical characterizations of the HBx-ssDNA interactions. J Biol Chem 1996, 271(26):15443-15450

37. Giglia-Mari G, Coin F, Ranish JA, Hoogstraten D, Theil A, Wijgers N, Jaspers NG, Raams A, Argentini M, van der Spek PJ, et al: A new, tenth subunit of TFIIH is responsible for the DNA repair syndrome trichothiodystrophy group A. Nat Genet 2004, 36(7):714-719.

38. Hashimoto S, Egly JM: Trichothiodystrophy view from the molecular basis of DNA repair/transcription factor TFIIH. Hum Mol Genet 2009, 18(R2): R224-230.

39. Scharer OD: Hot topics in DNA repair: the molecular basis for different disease states caused by mutations in TFIIH and XPG. DNA Repair (Amst) 2008, 7(2):339-344.

40. Seroz T, Hwang JR, Moncollin V, Egly JM: TFIIH: a link between transcription, DNA repair and cell cycle regulation. Curr Opin Genet Dev 1995, 5(2):217-221

41. Svejstrup JQ, Wang Z, Feaver WJ, Wu X, Bushnell DA, Donahue TF, Friedberg EC, Kornberg RD: Different forms of TFIIH for transcription and DNA repair: holo-TFIIH and a nucleotide excision repairosome. Cell 1995, 80(1):21-28.

42. Lee TH, Elledge SJ, Butel JS: Hepatitis B virus $X$ protein interacts with a probable cellular DNA repair protein. J Virol 1995, 69(2):1107-1114.

43. Aboussekhra A, Biggerstaff M, Shivji MK, Vilpo JA, Moncollin V, Podust VN, Protic M, Hubscher U, Egly JM, Wood RD: Mammalian DNA nucleotide excision repair reconstituted with purified protein components. Cell 1995, 80(6):859-868.

44. Aboussekhra A, Wood RD: Detection of nucleotide excision repair incisions in human fibroblasts by immunostaining for PCNA. Exp Cell Res 1995, 221(2):326-332.

45. Zhovmer A, Oksenych V, Coin F: Two sides of the same coin: TFIIH complexes in transcription and DNA repair. ScientificWorldJournal 2010 10:633-643.

46. Wood RD: DNA repair in eukaryotes. Annu Rev Biochem 1996, 65:135-167.

47. Wang Z, Svejstrup JQ, Feaver WJ, Wu X, Kornberg RD, Friedberg EC: Transcription factor $b(T F I I H)$ is required during nucleotide-excision repair in yeast. Nature 1994, 368(6466):74-76

48. Moggs JG, Szymkowski DE, Yamada M, Karran P, Wood RD: Differential human nucleotide excision repair of paired and mispaired cisplatin-DNA adducts. Nucleic Acids Res 1997, 25(3):480-491.

49. Shivji MK, Ferrari E, Ball K, Hubscher U, Wood RD: Resistance of human nucleotide excision repair synthesis in vitro to p21Cdn1. Oncogene 1998, 17(22):2827-2838.

50. Gulyas KD, Donahue TF: SSL2, a suppressor of a stem-loop mutation in the HIS4 leader encodes the yeast homolog of human ERCC-3. Cell 1992, 69(6):1031-1042

51. Benn J, Schneider RJ: Hepatitis B virus HBx protein deregulates cell cycle checkpoint controls. Proc Natl Acad Sci USA 1995, 92(24):11215-11219.

52. Shintani $Y$, Yotsuyanagi $H$, Moriya K, Fujie H, Tsutsumi T, Kanegae $Y$, Kimura S, Saito I, Koike K: Induction of apoptosis after switch-on of the hepatitis $B$ virus $X$ gene mediated by the Cre/loxP recombination system. J Gen Virol 1999, 80(Pt 12):3257-3265.

53. Bergametti F, Prigent S, Luber B, Benoit A, Tiollais P, Sarasin A, Transy C: The proapoptotic effect of hepatitis B virus $\mathrm{HBx}$ protein correlates with its transactivation activity in stably transfected cell lines. Oncogene 1999, 18(18):2860-2871.

54. Terradillos $\mathrm{O}$, Pollicino $\mathrm{T}$, Lecoeur $\mathrm{H}$, Tripodi $\mathrm{M}$, Gougeon $\mathrm{ML}$, Tiollais $\mathrm{P}$ Buendia MA: p53-independent apoptotic effects of the hepatitis $B$ virus $\mathrm{HBx}$ protein in vivo and in vitro. Oncogene 1998, 17(16):2115-2123.

55. Wang XW, Forrester K, Yeh H, Feitelson MA, Gu JR, Harris CC: Hepatitis B virus $X$ protein inhibits p53 sequence-specific DNA binding, transcriptional activity, and association with transcription factor ERCC3. Proc Natl Acad Sci USA 1994, 91(6):2230-2234.

56. Hannan MA, Hellani A, Al-Khodairy FM, Kunhi M, Siddiqui Y, Al-Yussef N, Pangue-Cruz N, Siewertsen M, Al-Ahdal MN, Aboussekhra A: Deficiency in the repair of UV-induced DNA damage in human skin fibroblasts compromised for the ATM gene. Carcinogenesis 2002, 23(10):1617-1624

57. Al-Mohanna MA, Al-Khodairy FM, Krezolek Z, Bertilsson PA, Al-Houssein KA, Aboussekhra A: p53 is dispensable for UV-induced cell cycle arrest at late $\mathrm{G}(1)$ in mammalian cells. Carcinogenesis 2001, 22(4):573-578.

58. Capovilla A, Carmona S, Arbuthnot P: Hepatitis B virus X-protein binds damaged DNA and sensitizes liver cells to ultraviolet irradiation. Biochem Biophys Res Commun 1997, 232(1):255-260

59. Al-Moghrabi NM, Al-Sharif IS, Aboussekhra A: UV-induced de novo protein synthesis enhances nucleotide excision repair efficiency in a transcription-dependent manner in S. cerevisiae. DNA Repair (Amst) 2003, 2(11):1185-1197.

60. Lee AT, Ren J, Wong ET, Ban KH, Lee LA, Lee CG: The hepatitis B virus $X$ protein sensitizes HepG2 cells to UV light-induced DNA damage. J Biol Chem 2005, 280(39):33525-33535.

61. Kim CM, Koike K, Saito I, Miyamura T, Jay G: HBx gene of hepatitis B virus induces liver cancer in transgenic mice. Nature 1991 351(6324):317-320.

62. Koike K, Moriya K, Yotsuyanagi H, lino S, Kurokawa K: Induction of cell cycle progression by hepatitis $B$ virus $\mathrm{HBx}$ gene expression in quiescent mouse fibroblasts. J Clin Invest 1994, 94(1):44-49.

63. Slagle BL, Lee TH, Medina D, Finegold MJ, Butel JS: Increased sensitivity to the hepatocarcinogen diethylnitrosamine in transgenic mice carrying the hepatitis B virus X gene. Mol Carcinog 1996, 15(4):261-269.

64. Terradillos O, Billet $O$, Renard CA, Levy R, Molina T, Briand P, Buendia MA: The hepatitis $B$ virus $X$ gene potentiates c-myc-induced liver oncogenesis in transgenic mice. Oncogene 1997, 14(4):395-404.

65. Hoeijmakers JH: Human nucleotide excision repair syndromes: molecular clues to unexpected intricacies. Eur J Cancer 1994, 30A(13):1912-1921.

66. Chu G, Mayne L: Xeroderma pigmentosum, Cockayne syndrome and trichothiodystrophy: do the genes explain the diseases? Trends Genet 1996, 12(5):187-192.

67. Selby CP, Sancar A: Molecular mechanism of transcription-repair coupling. Science 1993, 260(5104):53-58

68. Lindahl T, Karran P, Wood RD: DNA excision repair pathways. Curr Opin Genet Dev 1997, 7(2):158-169.

69. Al-Mohanna MA, Manogaran PS, Al-Mukhalafi Z, K AA-H, Aboussekhra A: The tumor suppressor p16(INK4a) gene is a regulator of apoptosis induced by ultraviolet light and cisplatin. Oncogene 2004, 23(1):201-212.

70. Goodrich JA, Tjian R: Transcription factors IIE and IIH and ATP hydrolysis direct promoter clearance by RNA polymerase II. Cell 1994, 77(1):145-156.

71. Sancar A: Excision repair in mammalian cells. J Biol Chem 1995, 270(27):15915-15918.

72. Rossner MT: Review: hepatitis B virus X-gene product: a promiscuous transcriptional activator. J Med Virol 1992, 36(2):101-117.

73. Mathonnet G, Lachance S, Alaoui-Jamali M, Drobetsky EA: Expression of hepatitis $B$ virus $X$ oncoprotein inhibits transcription-coupled nucleotide excision repair in human cells. Mutat Res 2004, 554(1-2):305-318.

74. Tang H, Oishi N, Kaneko S, Murakami S: Molecular functions and biological roles of hepatitis B virus x protein. Cancer Sci 2006, 97(10):977-983.

75. Ma NF, Lau SH, Hu L, Xie D, Wu J, Yang J, Wang Y, Wu MC, Fung J, Bai X, et al: $\mathrm{COOH}$-terminal truncated $\mathrm{HBV} X$ protein plays key role in hepatocarcinogenesis. Clin Cancer Res 2008, 14(16):5061-5068.

76. Baptista M, Kramvis A, Kew MC: High prevalence of 1762(T) 1764(A) mutations in the basic core promoter of hepatitis B virus isolated from black Africans with hepatocellular carcinoma compared with asymptomatic carriers. Hepatology 1999, 29(3):946-953.

77. Kekule AS, Lauer U, Weiss L, Luber B, Hofschneider PH: Hepatitis B virus transactivator $\mathrm{HBx}$ uses a tumour promoter signalling pathway. Nature 1993, 361(6414):742-745.

78. Doria M, Klein N, Lucito R, Schneider RJ: The hepatitis B virus HBx protein is a dual specificity cytoplasmic activator of Ras and nuclear activator of transcription factors. EMBO J 1995, 14(19):4747-4757.

79. Klein NP, Schneider RJ: Activation of Src family kinases by hepatitis B virus HBx protein and coupled signaling to Ras. Mol Cell Biol 1997 17(11):6427-6436.

80. Hsu T, Moroy T, Etiemble J, Louise A, Trepo C, Tiollais P, Buendia MA: Activation of c-myc by woodchuck hepatitis virus insertion in hepatocellular carcinoma. Cell 1988, 55(4):627-635.

81. Takada S, Gotoh Y, Hayashi S, Yoshida M, Koike K: Structural rearrangement of integrated hepatitis $B$ virus DNA as well as cellular 
flanking DNA is present in chronically infected hepatic tissues. J Virol 1990, 64(2):822-828.

82. Buetow KH, Sheffield VC, Zhu M, Zhou T, Shen FM, Hino O, Smith M, McMahon BJ, Lanier AP, London WT, et al: Low frequency of p53 mutations observed in a diverse collection of primary hepatocellular carcinomas. Proc Natl Acad Sci USA 1992, 89(20):9622-9626.

83. Urano $Y$, Watanabe $K$, Lin CC, Hino O, Tamaoki T: Interstitial chromosomal deletion within 4q11-q13 in a human hepatoma cell line. Cancer Res 1991, 51(5):1460-1464.

84. Natoli G, Avantaggiati ML, Chirillo P, Costanzo A, Artini M, Balsano C, Levrero M: Induction of the DNA-binding activity of c-jun/c-fos heterodimers by the hepatitis B virus transactivator pX. Mol Cell Biol 1994, 14(2):989-998.

85. Natoli G, Avantaggiati ML, Chirillo P, Puri PL, lanni A, Balsano C, Levrero M: Ras- and Raf-dependent activation of C-jun transcriptional activity by the hepatitis B virus transactivator pX. Oncogene 1994, 9(10):2837-2843.

86. Benn J, Su F, Doria M, Schneider RJ: Hepatitis B virus HBx protein induces transcription factor AP-1 by activation of extracellular signal-regulated and c-Jun N-terminal mitogen-activated protein kinases. J Virol 1996, 70(8):4978-4985.

87. Huang SN, Chisari FV: Strong, sustained hepatocellular proliferation precedes hepatocarcinogenesis in hepatitis B surface antigen transgenic mice. Hepatology 1995, 21(3):620-626.

88. Hsieh YH, Su IJ, Wang HC, Chang WW, Lei HY, Lai MD, Chang WT, Huang W: Pre-S mutant surface antigens in chronic hepatitis B virus infection induce oxidative stress and DNA damage. Carcinogenesis 2004, 25(10):2023-2032.

89. Shinmura K, Yokota J: The OGG1 gene encodes a repair enzyme for oxidatively damaged DNA and is involved in human carcinogenesis. Antioxid Redox Signal 2001, 3(4):597-609.

doi:10.1186/1471-2180-11-48

Cite this article as: Qadri et al: Hepatitis B virus $X$ protein impedes the DNA repair via its association with transcription factor, TFIIH. BMC

Microbiology 2011 11:48.

\section{Submit your next manuscript to BioMed Central} and take full advantage of:

- Convenient online submission

- Thorough peer review

- No space constraints or color figure charges

- Immediate publication on acceptance

- Inclusion in PubMed, CAS, Scopus and Google Scholar

- Research which is freely available for redistribution

Submit your manuscript at www.biomedcentral.com/submit
Biomed Central 